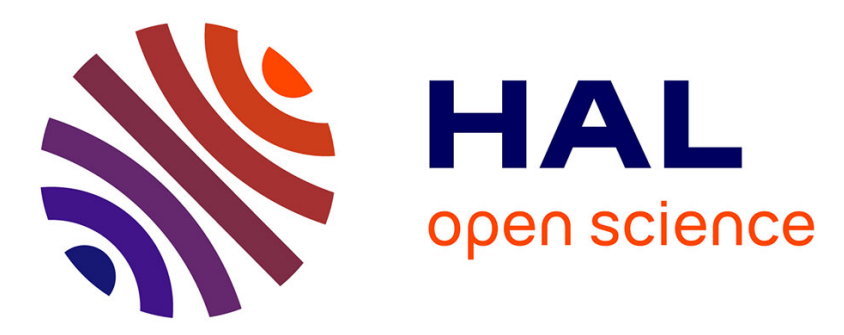

\title{
Oligo(ethylene glycol) (OEG) functionalized 2-(2'-Hydroxy benzofuranyl) benzoxazole (HBBO) derivatives: Synthesis, photophysical properties and biomolecules binding studies
}

\author{
Abdellah Felouat, Julien Massue, Gilles Ulrich
}

\section{To cite this version:}

Abdellah Felouat, Julien Massue, Gilles Ulrich. Oligo(ethylene glycol) (OEG) functionalized 2-(2'-Hydroxy benzofuranyl) benzoxazole (HBBO) derivatives: Synthesis, photophysical properties and biomolecules binding studies. Dyes and Pigments, 2020, 185, pp.108895. 10.1016/j.dyepig.2020.108895 . hal-03102056

\section{HAL Id: hal-03102056 https://hal.science/hal-03102056}

Submitted on 26 Nov 2021

HAL is a multi-disciplinary open access archive for the deposit and dissemination of scientific research documents, whether they are published or not. The documents may come from teaching and research institutions in France or abroad, or from public or private research centers.
L'archive ouverte pluridisciplinaire HAL, est destinée au dépôt et à la diffusion de documents scientifiques de niveau recherche, publiés ou non, émanant des établissements d'enseignement et de recherche français ou étrangers, des laboratoires publics ou privés. 


\title{
Oligo(ethylene glycol) (OEG) functionalized 2-(2'-Hydroxy benzofuranyl) benzoxazole (HBBO) derivatives: Synthesis, photophysical properties and biomolecules binding studies
}

\author{
Abdellah Felouat, Julien Massue *, Gilles Ulrich * \\ Institut de Chimie et Procédés pour L'Energie, L'Environnement et La Santé (ICPEES), Equipe Chimie Organique pour La Biologie, Les Matériaux et L'Optique (COMBO), \\ UMR CNRS 7515, Ecole Européenne de Chimie, Polymères et Matériaux (ECPM), 25 Rue Becquerel, 67087, Strasbourg Cedex 02, France
}

\begin{abstract}
A B S T R A C T
Two molecular fluorophores based on a 2-(2'-Hydroxybenzofuranyl) benzoxazole (HBBO) scaffold and presenting an Excited-State Intramolecular Proton Transfer (ESIPT) process are reported herein. These dyes incorporate strongly electrodonating aromatic amino groups on the benzofuranyl side, enabling the appearance of a dual fluorescence emission corresponding to the radiative decay of the excited enol $\left(\mathrm{E}^{*}\right)$ and keto $\left(\mathrm{K}^{*}\right)$ tautomers at high and low energy respectively. It was previously demonstrated that dual $\mathrm{E}^{*} / \mathrm{K}^{*}$ emission could originate from a beneficial decrease of phenolic acidity upon absorption of light leading to a thermodynamic stabilization of the first excited-state. The innovation within these dyes lies in the double functionalization of the aniline moiety with 2-(2-methoxyethoxy)ethyl units which allowed a better solubilization in protic solvents, as compared to their butyl analogs while keeping strong electrodonating capacity. Their intrinsic amphiphilic character leads to a good vectorization in a wide range of solvents from toluene to PBS buffer. The investigation of the photophysical properties of these dyes in solution showed a clear dual emission in apolar solvents with the $\mathrm{E}^{*}$ band gradually red-shifting along with the dipole moment of the solvent. Dual emission is also observed in the solid-state when these dyes are doped as 1\%wt in PMMA or PS films. Finally, the interactions of one dye with calf-thymus (ct)-DNA and Bovine Serum Albumin (BSA) have been explored and reveal pronounced modifications of the UV-Vis profile of the dye. Additionally, a gradual hypsofluorochromic shift and narrowing of the $\mathrm{K}^{*}$ band along with the appearance of the $\mathrm{E}^{*}$ fluorescence band upon addition of ct-DNA or BSA is also observed, presumably evidencing an intercalation mode of binding.
\end{abstract}

\section{Introduction}

The search for original Excited-State Intramolecular Proton Transfer (ESIPT) molecular structures has motivated numerous studies, owing to their outstanding photoluminescent properties, that are enhanced Stokes shifts, strong solid-state luminescence and environment-sensitive fluorescence profiles [1]. Challenging applications in the field of optoelectronics [2], bio-sensing [3], smart security inks [4], among others [5] have arisen from this unique class of fluorophores. In order to expand the scope of ESIPT-capable molecular dyes and enrich this field with additional properties, many different ESIPT fluorophores have been reported over the years to tackle these challenges, including recent elegant examples [6]. A common feature in the design of ESIPT emitters lies in the presence of a strong hydrogen bond in the ground state (enol form, E) which initiates an internal proton transfer from the excited-state $\mathrm{E}^{*}$ leading to the excited tautomeric keto species $\left(\mathrm{K}^{*}\right)$. In most cases, the radiative decay from the $\mathrm{K}^{*}$ state translates into the sole appearance of a red-shifted $\mathrm{K}^{*}$ emission band. The proton transfer has been shown to be extremely fast, in the sub-picosecond range, but in some cases, a partial proton back-transfer is observed leading to a dual decay from both $E^{*}$ and $K^{*}$ states (Fig. 1) [7]. This dual emission is observed when the first excited state is energetically stabilized via solvent interactions or increase of the $\mathrm{pK}_{\mathrm{a}}{ }^{*}$ of the proton donor owing to electronic effects, with a potential competition with deprotonation [8].

Dual emission from monomolecular species can be particularly appealing, as it can be lead to the production of panchromatic white emission, a feature of high potential for the engineering of white-OLEDs [9]. In this context, ESIPT-capable 2-(2'-Hydroxybenzofuranyl) benzazole (HBBX) derivatives have proven to be excellent versatile scaffolds to achieve panchromatic dual $\mathrm{E}^{*} / \mathrm{K}^{*}$ emission in solution and in the solid-state [10]. A structure/optical properties relationship study allowed the fine-tuning of the $\mathrm{pK}_{\mathrm{a}} \mathrm{s}$ of the proton donor and acceptor in HBBX systems and the modulation of the $\mathrm{E}^{*} / \mathrm{K} *$ intensity ratio leading to unique environment-sensitive spectroscopic signatures [11]. Examples of dual-emitting HBBX-based ESIPT emitters are represented on Fig. 2a. Along with the majority of heterocyclic dyes, ESIPT-based fluorophores

\footnotetext{
* Corresponding author.

$* *$ Corresponding author.

E-mail address: massue@unistra.fr (J. Massue).
} 


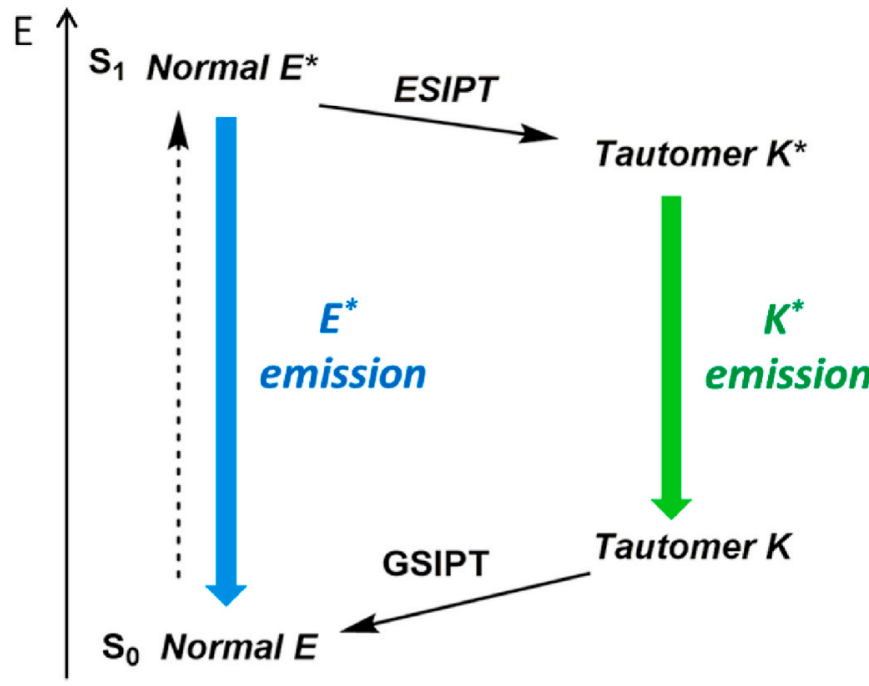

Fig. 1. Schematic representation of the ESIPT process showing dual emission from $\mathrm{E}^{*}$ and $\mathrm{K}^{*}$ states.

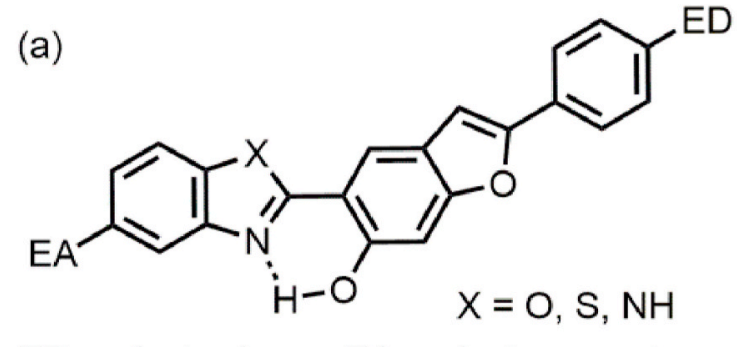

$\mathrm{ED}=$ electrodonor, $\mathrm{EA}=$ electroacceptor<smiles>[R]C#Cc1cc(C#C[R])c2c(c1)N[n+]1oc3cc4oc(-c5ccc(NCCC)cc5)c(C#C[R])c4cc3c1O2</smiles><smiles>[R]=[As]CCOCCOCCOCCOCCOC</smiles>

Fig. 2. (a) Dual emissive HBBX fluorophores and (b) Water soluble tris-OEG functionalized HBBO fluorophore.

are hydrophobic by nature and their vectorization in aqueous medium remains an issue. However, this challenge needs to be tackled in order to target biological applications such as cellular imaging and in vivo sensing of biosubstrates [12]. Two strategies are generally adopted: either an encapsulation of organic dyes in amphiphilic polymers such as pluronic or cremaphor derivatives [13] or a functionalization of the organic scaffold with charged, neutral or zwitterionic hydrophilic moieties in order to trigger complete or partial hydrosolubility [14]. We recently chose to investigate the second option by functionalizing several positions of the core of HBBO derivatives with long oligo(ethylene glycol) (OEG) chains and assess their photophysical properties [15]. A good vectorization in aqueous medium (PBS buffer/DMSO 95:5) was achieved and $\mathrm{E}^{*} / \mathrm{K}^{*}$ dual emission was observed in solution and in the solid-state. However, the presence of highly hydrophobic butyl chains on the nitrogen required the presence of three OEG chains for an efficient solubilization in water (Fig. 2b).

Tedious synthetic protocols and purification steps were therefore necessary and triggered our curiosity to find alternative ways to vectorize HBBX dyes in aqueous medium.

In this article, an alternative synthetic approach is described, that consists in the direct $\mathrm{N}$-alkylation of the terminal aromatic amine by 2 (2-methoxyethoxy)ethyl units in order to maintain a strong electron donating ability on the phenol side and improve water solubility and biocompatibility. Moreover, the 2-(2-methoxyethoxy)ethyl amino group has been recently described as a good intercalation group in the DNA double helix through hydrogen bonding [16]. Therefore, we anticipate that the introduction of a similar moiety on the amino side will not only contribute to the overall hydrophilicity of the HBBX probes but also to the potential use of these dyes to probe interactions with biomacromolecules such as DNA. Indeed, dual-emitting ESIPT dyes have been used in the past as sensors to probe the polarity changes in microenvironments [17]. Following this strategy, two HBBO dyes are herein described, named 1 and $\mathbf{2}$ (Fig. 3). Having established previously that dual emission is attainable via the introduction of electrowithdrawing groups [10] or ethynyl extension [15] on the benzoxazole side, these two approaches are considered and compared. The photophysical properties in solution in a wide range of solvents and in the solid-state, as doped in polymers are evaluated. Finally, the interactions of HBBO dye 1 with calf-thymus (ct)-DNA and BSA are studied.

\section{Synthesis}

The preparation of HBBO dyes $\mathbf{1}$ and $\mathbf{2}$ is described on Schemes 1 and 2 , respectively.

The first step was the formation of salicylaldehyde derivative $\mathbf{7}$ from acetylide 5 using classical Sonogashira Pd-catalyzed cross-coupling reaction conditions. Compound 7 is obtained as a yellow powder in $50 \%$<smiles></smiles><smiles>[R]C#Cc1cc(C#C[R])c2oc(-c3cc4cc(-c5ccc(N([R])[R])cc5)oc4cc3O)[n+](OCCOCCOCCOCCOCCOCCOC)c2c1</smiles>

Fig. 3. (a) HBBO dye 1, (b) HBBO dye 2 studied in this article. 


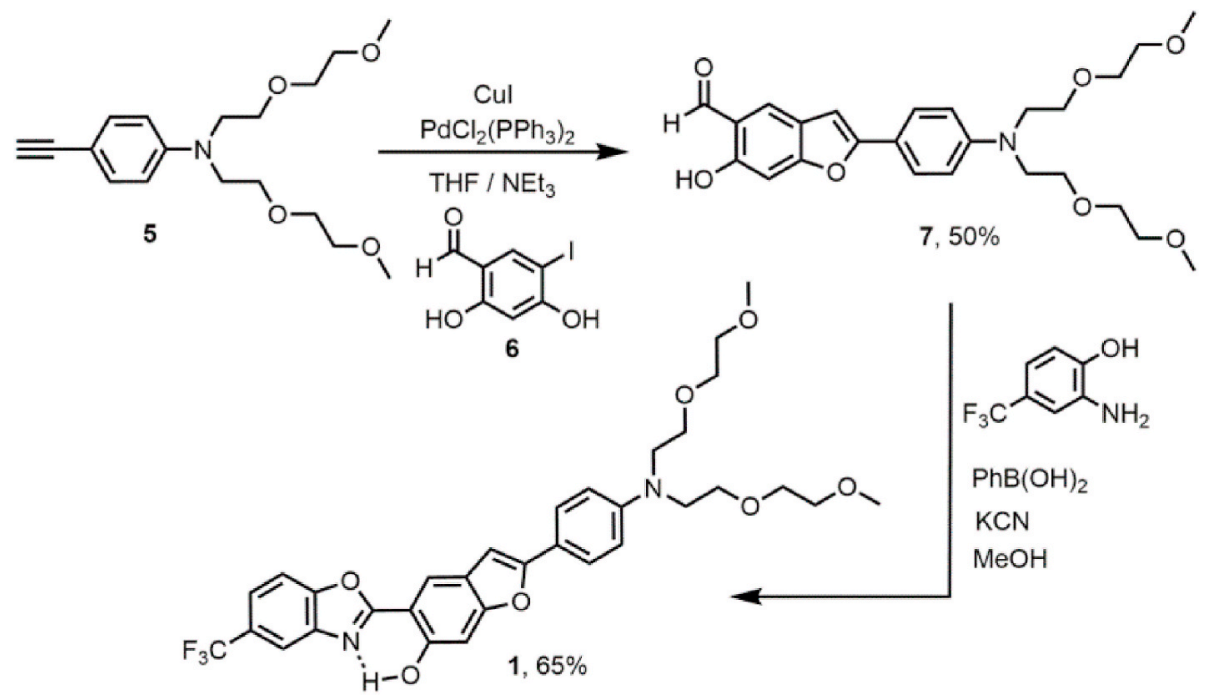

Scheme 1. Synthesis of HBBO dye 1.

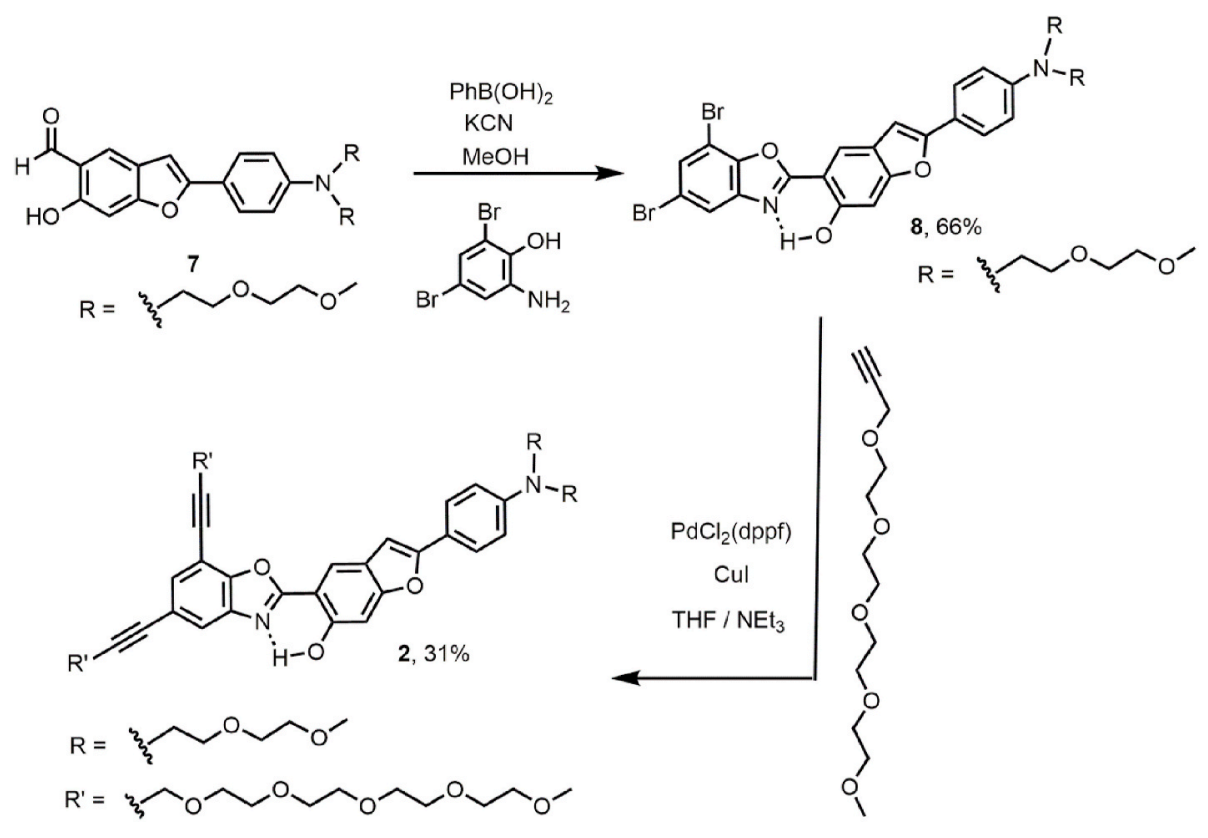

Scheme 2. Synthesis of HBBO dye 2.

yield (Scheme 1). The HBBO scaffold was then constructed by reacting 7 with 4-trifluoromethane- or 4,6-dibromo- 2-aminophenol derivatives in methanol with an excess of phenylboronic acid and potassium cyanide. HBBO 1 and bis-bromo HBBO 8 were obtained in 65\% and 66\% yield respectively. HBBO 8 was further reacted with a catalytic amount of $\mathrm{PdCl}_{2}$ (dppf) with an excess of 2,5,8,11,14-pentaoxaheptadec-16-yne to yield HBBO dye 2 which incorporates two OEG chains at the benzoxazole side (Scheme 2).

The introduction of the 2-(2-methoxyethoxy)ethyl amino group along with the absence of the lipophilic dibutyl chains translated in a pronounced amphiphilic character for HBBO dyes $\mathbf{1}$ and $\mathbf{2}$ and triggered an enhanced solubility in a wide range of solvents, including pure PBS buffer (pH 7.4) at micromolar concentrations.

All compounds were characterized by ${ }^{1} \mathrm{H}$ and ${ }^{13} \mathrm{C}$ NMR spectroscopy, as well as HR-MS spectrometry. The ${ }^{1} \mathrm{H}$ NMR spectra of $\mathbf{1}$ and $\mathbf{2}$ were characterized by the presence of a distinctive downfield proton signal resonating between 11 and $11.5 \mathrm{ppm}$, attributed to the H-bonded phenolic proton. The methylene protons at the $\alpha$ position of the $\mathrm{sp}$ carbon or attached to the nitrogen can be clearly discriminated in the ${ }^{1} \mathrm{H}$ NMR spectrum of 2 (singlets at 4.28 and 4.58 ppm or multiplets at 3.86-3.87 and 3.77-3.79 ppm respectively). Moreover, two distinct singlets corresponding to the terminal methoxy group protons on the benzoxazole side were observed at 3.36 and $3.38 \mathrm{ppm}$, evidencing the incorporation of two distinct OEG chains in the structure of 2.

\section{Experimental section}

\subsection{Materials and methods}

All chemicals were received from commercial sources (Sigma Aldrich, Fluorochem) and used without further purification. Tetrahydrofuran (THF) was distilled over metallic sodium (Na). Dichloromethane (DCM) was distilled over $\mathrm{P}_{2} \mathrm{O}_{5}$ under an argon atmosphere. Triethylamine $\left(\mathrm{Et}_{3} \mathrm{~N}\right)$ was distilled under argon over $\mathrm{KOH}$. Thin layer chromatography (TLC) was performed on silica gel coated with fluorescent indicator. Chromatographic purifications were conducted using 
40-63 $\mu \mathrm{m}$ silica gel.

${ }^{1} \mathrm{H}$ NMR (400 or $500 \mathrm{MHz}$ ) and ${ }^{13} \mathrm{C}$ NMR (100 or $125 \mathrm{MHz}$ ) spectra were recorded on a Bruker Advance 400 or $500 \mathrm{MHz}$ spectrometers with perdeuterated solvents with residual protonated solvent signals as internal references. Absorption spectra were recorded using a dual-beam grating Schimadzu UV-3000 absorption spectrometer with a quartz cell of $1 \mathrm{~cm}$ of optical path length. The steady-state fluorescence emission and excitation spectra were recorded by using a Horiba S2 Jobin Yvon Fluoromax 4. All fluorescence and excitation spectra were corrected. Solvents for spectroscopy were spectroscopic grade and were used as received.

The fluorescence quantum yields were calculated according to a method presented in section S5.1.

Luminescence lifetimes were measured on an Edinburgh Instruments spectrofluorimeter equipped with a R928 photomultiplier and a PicoQuant PDL 800-D pulsed diode connected to a GwInstect GFG-8015G delay generator. No filter was used for the excitation. Emission wavelengths were selected by a monochromator. Lifetimes were deconvoluted with FS-900 software using a light-scattering solution (LUDOX) for instrument response. The excitation source was a laser diode $\left(\lambda_{\text {exc }}=320\right.$ $\mathrm{nm})$.

4-ethynyl- $N, N$-bis[2-(2-methoxyethoxy)ethyl]-benzenamine 5 [18] and 2,5,8,11,14-pentaoxa-hepta dec-16-yne [19] were synthesized according to reported procedures.

Calf thymus DNA (ct-DNA) was purchased from Sigma Aldrich and used without further purification. The homogeneous stock solutions of $c t$-DNA were prepared in Tris $\mathrm{HCl}$ buffer (pH 7.4, $10 \mathrm{mM}$ ) and kept at $4{ }^{\circ} \mathrm{C}$. The concentration of ct-DNA was estimated spectrophotometrically by using the molar absorption coefficient, $\varepsilon$ DNA $=6600 \mathrm{M}^{-1} \mathrm{~cm}^{-1}$ at $\lambda_{\text {abs }}=260 \mathrm{~nm}$. Bovine Serum Albumine (BSA) was purchased from Sigma Aldrich and used without further purification. The stock solutions of BSA were prepared in PBS buffer (pH 7.4) and kept at $4{ }^{\circ} \mathrm{C}$.

Salicylaldehyde 7: In a Schlenk tube, salicylaldehyde 6 and [Pd $\left.\left(\mathrm{PPh}_{3}\right)_{2} \mathrm{Cl}_{2}\right](5 \% \mathrm{~mol})$ were dissolved in a mixture of THF/triethylamine $(3: 1 \mathrm{v} / \mathrm{v})$. The resulting suspension was degassed with argon for $30 \mathrm{~min}$ before 4-ethynyl-N,N-bis[2-(2-methoxyethoxy)ethyl]-benzenamine $\mathbf{5}$ (1.5 eqts) was added followed by $\mathrm{CuI}(10 \% \mathrm{~mol})$. The resulting mixture was stirred overnight at $60^{\circ} \mathrm{C}$. After cooling down, the dark solution was evaporated under vacuum before dichloromethane was added. The organic phase was washed with water three times, dried over $\mathrm{MgSO}_{4}$ then concentrated under vacuum. The crude residue was purified by silica gel chromatography (ethyl acetate). Yellow oil. 50\%, ${ }^{1} \mathrm{H}$ NMR $\left(500 \mathrm{MHz}, \mathrm{CDCl}_{3}\right): \delta(\mathrm{ppm})=11.22(\mathrm{~s}, 1 \mathrm{H}, \mathrm{OH}), 9.91(\mathrm{~s}, 1 \mathrm{H}, \mathrm{OH})$, 7.64-7.66 (m, 3H, CH), $7.03(\mathrm{~s}, 1 \mathrm{H}, \mathrm{CH}), 6.79\left(2 \mathrm{H}, \mathrm{d}, \mathrm{CH},{ }^{3} \mathrm{~J}=12 \mathrm{~Hz}\right)$, $6.72(\mathrm{~s}, 1 \mathrm{H}, \mathrm{CH}), 3.61-3.67\left(\mathrm{~m}, 12 \mathrm{H}, \mathrm{CH}_{2}\right), 3.53-3.55\left(\mathrm{~m}, 4 \mathrm{H}, \mathrm{CH}_{2}\right)$, $3.39\left(\mathrm{~s}, 6 \mathrm{H}, \mathrm{CH}_{3}\right) .{ }^{13} \mathrm{C} \mathrm{NMR}\left(125 \mathrm{MHz}, \mathrm{CDCl}_{3}\right): \delta(\mathrm{ppm})=195.9,159.8$, 159.8, 158.4, 148.3, 126.3, 125.8, 123.7, 117.9, 117.4, 111.7, 99.1, 97.1, 72.0, 70.7, 68.4, 59.1, 50.9. HRMS: calculated $(\mathrm{M}+\mathrm{H}+$ ): 458.2113, found $(\mathrm{M}+\mathrm{H}+)$ : 458.2189.

HBO 1: In a round-bottomed flask, phenylboronic acid (1.2 eqts) and potassium cyanide (3 eqts) were added to a solution of salicylaldehyde 7 in methanol. 4-trifuoromethane-2-aminophenol (1.1 eq) was then added and the mixture was stirred at room temperature overnight. The reaction mixture was then concentrated under vacuum, and the crude residue was purified by column chromatography on silica gel eluting with $\mathrm{CH}_{2} \mathrm{Cl}_{2}$ /petroleum ether $(1: 3 v / v)$. Yellow powder. $65 \%$. ${ }^{1} \mathrm{H}$ NMR (500 $\left.\mathrm{MHz}, \mathrm{CDCl}_{3}\right): \delta(\mathrm{ppm})=11.35(\mathrm{~s}, 1 \mathrm{H}, \mathrm{OH}), 8.16(\mathrm{~s}, 1 \mathrm{H}, \mathrm{CH}), 8.02(\mathrm{~s}, 1 \mathrm{H}$, $\mathrm{CH}), 7.64-7.72(\mathrm{~m}, 4 \mathrm{H}, \mathrm{CH}), 7.21(\mathrm{~s}, 1 \mathrm{H}, \mathrm{CH}), 6.78\left(\mathrm{~d}, 2 \mathrm{H},{ }^{3} \mathrm{~J}=10 \mathrm{~Hz}\right)$, 6.75 (s, $1 \mathrm{H}, \mathrm{CH}), 3.62-3.68\left(\mathrm{~m}, 12 \mathrm{H}, \mathrm{CH}_{2}\right), 3.54-3.56\left(\mathrm{~m}, 4 \mathrm{H}, \mathrm{CH}_{2}\right)$, $3.40\left(\mathrm{~s}, 6 \mathrm{H}, \mathrm{CH}_{3}\right) .{ }^{13} \mathrm{C} \mathrm{NMR}\left(125 \mathrm{MHz}, \mathrm{CDCl}_{3}\right): \delta(\mathrm{ppm})=165.4,158.9$, $157.9,156.9,150.9,148.2,140.5,126.3,123.5,122.3,122.3,118.4$, $117.3,116.6,111.7,110.9,106.3,99.5,97.2,72.0,70.7,68.4,59.2$, 51.0. HRMS: calculated $(M+H+)$ : 615.2313 , found $(M+H+)$ : 615.2314.

HBO 8: In a round-bottomed flask, phenylboronic acid (1.2 eqts) and potassium cyanide ( 3 eqts) were added to a solution of salicylaldehyde 7 in methanol. 4,6-dibromo-2-aminophenol (1.1 eq) was then added and the mixture was stirred at room temperature overnight. The reaction mixture was then concentrated under vacuum, and the crude residue was purified by column chromatography on silica gel eluting with $\mathrm{CH}_{2} \mathrm{Cl}_{2}$ /petroleum ether $(1: 3 v / v)$. Yellow powder. $66 \% .{ }^{1} \mathrm{H}$ NMR $(500$ $\mathrm{MHz}, \mathrm{CDCl}_{3}$ ): 11.08 (s, OH, 1H), $8.13(\mathrm{~s}, 1 \mathrm{H}, \mathrm{CH}), 7.76(\mathrm{~s}, 1 \mathrm{H}, \mathrm{CH})$, 7.61-7.65 (m, 3H, CH), $7.17(\mathrm{~s}, 1 \mathrm{H}, \mathrm{CH}), 6.77\left(\mathrm{~d}, 1 \mathrm{H}, \mathrm{CH}_{2},{ }^{3} \mathrm{~J}=10 \mathrm{~Hz}\right)$, $6.72(\mathrm{~s}, 1 \mathrm{H}, \mathrm{CH}), 3.62-3.68\left(\mathrm{~m}, \mathrm{CH}_{2}, 12 \mathrm{H}\right), 3.54-3.56\left(\mathrm{~m}, \mathrm{CH}_{2}, 4 \mathrm{H}\right)$, $3.40\left(\mathrm{~s}, 6 \mathrm{H}, \mathrm{CH}_{3}\right) .{ }^{13} \mathrm{C}$ NMR $\left(125 \mathrm{MHz}, \mathrm{CDCl}_{3}\right): \delta(\mathrm{ppm})=164.8,158.7$, $157.9,156.9,148.2,146.7,142.0,130.5,126.3,123.6,121.0,118.6$, 117.9, 117.7, 111.7, 106.0, 103.2, 99.4, 97.2, 72.0, 70.7, 68.4, 59.2, 51.0. HRMS: calculated $(\mathrm{M}+\mathrm{H}+)$ : 726.0501 , found $(\mathrm{M}+\mathrm{H}+)$ : 726.0491 .

HBO 2 [20]: In a Schlenk tube, HBO 8 and [Pd(dppf)Cl ${ }_{2}$ ] (5\% mol) were dissolved in a mixture of THF/triethylamine $(3: 1 \mathrm{v} / \mathrm{v})$. The resulting suspension was degassed with argon for $30 \mathrm{~min}$ before $2,5,8$, 11,14-pentaoxahepta dec-16-yne (1.5 eqts) was added followed by CuI $(10 \% \mathrm{~mol})$. The resulting mixture was stirred overnight at $60{ }^{\circ} \mathrm{C}$. After cooling down, the dark solution was evaporated and the crude residue was purified by silica gel chromatography $\left(\mathrm{CH}_{2} \mathrm{Cl}_{2}\right.$ /ethyl acetate $9 / 1$ to ethyl acetate $100 \%$ ). Yellow oil. $31 \% .{ }^{1} \mathrm{H}$ NMR (400 MHz, $\left.\mathrm{CDCl}_{3}\right): 11.22$ (s, $1 \mathrm{H}, \mathrm{OH}), 8.19$ (s, $1 \mathrm{H}, \mathrm{CH}), 7.81(\mathrm{~s}, 1 \mathrm{H}, \mathrm{CH}), 7.67$ (d, $2 \mathrm{H}, \mathrm{CH},{ }^{3} J=5$ $\mathrm{Hz}$ ), 7.55 (s, 1H, CH), 7.19 (s, 1H, CH), 6.76-6.78 (m, 3H, CH), 4.58 (s, $\left.2 \mathrm{H}, \mathrm{CH}_{2}\right), 4.28\left(\mathrm{~s}, 2 \mathrm{H}, \mathrm{CH}_{2}\right), 3.86-3.87\left(\mathrm{~m}, 2 \mathrm{H}, \mathrm{CH}_{2}\right), 3.77-3.79(\mathrm{~m}, 2 \mathrm{H}$, $\left.\mathrm{CH}_{2}\right), 3.61-3.72\left(\mathrm{~m}, 34 \mathrm{H}, \mathrm{CH}_{2}\right), 3.52-3.56\left(\mathrm{~m}, 10 \mathrm{H}, \mathrm{CH}_{2}\right), 3.39(\mathrm{~s}, 6 \mathrm{H}$, $\left.\mathrm{CH}_{3}\right), 3.38\left(\mathrm{~s}, 3 \mathrm{H}, \mathrm{CH}_{3}\right), 3.36\left(\mathrm{~s}, 3 \mathrm{H}, \mathrm{CH}_{3}\right) .{ }^{13} \mathrm{C} \mathrm{NMR}\left(100 \mathrm{MHz}, \mathrm{CDCl}_{3}\right): \delta$ $(\mathrm{ppm})=165.0,158.7,157.9,156.9,148.5,148.2,141.7,131.1,126.3$, 123.6, 122.4, 118.7, 117.8, 117.2, 111.7, 107.9, 106.2, 99.4, 97.3, 92.0, 78.7, 75.4, 72.0, 72.0, 72.0, 70.8, 70.7, 70.6, 70.6, 70.6, 70.6, 70.5, 70.4, 69.5, 69.4, 68.4, 59.3, 59.2, 59.0, 51.0.

\subsection{Photophysical properties}

The photophysical properties of HBBO dyes $\mathbf{1}$ and $\mathbf{2}$ have been studied in solution in a wide range of solvents of different polarity and as doped in polymers. The photophysical data are presented in Tables 1 and 2.

The absorption spectra in solution for HBBO dyes $\mathbf{1}$ and $\mathbf{2}$ are presented on Figs. 4 and 5.

HBBO dyes 1 and $\mathbf{2}$ exhibit similar absorption profiles, i.e. a main broad absorption band, corresponding to the $S_{0}-S_{1}$ transition with very little influence of the nature of the solvent. Specifically, absorption maximum wavelengths are in the range $378 / 390 \mathrm{~nm}$ and $385 / 392 \mathrm{~nm}$ with molar absorption coefficients from 18500 to $35100 \mathrm{M}^{-1} \mathrm{~cm}^{-1}$ and 16700 and $24100 \mathrm{M}^{-1} \mathrm{~cm}^{-1}$ for $\mathbf{1}$ and 2 , respectively. Introduction of two OEG chains on the benzoxazole ring led to a slight bathochromic and hypochromic shift of the absorption band. Protonation of the aromatic amine by bubbling gaseous $\mathrm{HCl}$ in dichloromethane solution triggers a pronounced hypsochromic shift for both dyes $\left(\lambda_{\mathrm{abs}}=358 \mathrm{~nm}\right.$ for the protonated form of 1 and $2 v s . \lambda_{\text {abs }}=383 / 391 \mathrm{~nm}$ in their neutral state, respectively). The additional absorption bands observed at higher energies (below $300 \mathrm{~nm}$ ) are assigned to the $\pi-\pi^{*}$ transitions of the phenyl rings. These absorption profiles are usually observed for related HBBO dyes [10,11].

It is worth noting that in ethanol for $\mathbf{1}$ and in PBS buffer for $\mathbf{1}$ and $\mathbf{2}$, low intensity additional bands are observed above $450 \mathrm{~nm}$ which could be attributed to the minor presence of the $\mathrm{K}$ tautomer in the ground states, according to publications describing related systems [21].

Upon irradiation at $390 \mathrm{~nm}, \mathrm{HBBO}$ dyes $\mathbf{1}$ and $\mathbf{2}$ display one or two intense emission bands assigned to the radiative decay either from the $\mathrm{K}^{*}$ or $\mathrm{E}^{*} / \mathrm{K}^{*}$ excited states $\left(\lambda_{\mathrm{em}}=470-582 \mathrm{~nm}\right.$ and $471-599 \mathrm{~nm}$ for 1 and $\mathbf{2}$, respectively). The emission spectra in solution and solid-state are presented on Figs. 6-8 respectively.

This photophysical behavior is typically observed for similar fluorophores $[10,11]$ and can be explained by the presence of a strong electron donor, in this case the 2-(2-methoxyethoxy)ethyl amino group, 
Table 1

Photophysical data for HBBO dye 1 recorded in aerated solutions of various solvents at $25{ }^{\circ} \mathrm{C}$ and in the solid-state.

\begin{tabular}{|c|c|c|c|c|c|c|c|c|}
\hline Solvent & $\lambda_{\mathrm{abs}}(\mathrm{nm})$ & $\varepsilon\left(\mathrm{M}^{-1} \cdot \mathrm{cm}^{-1}\right)$ & $\lambda_{\mathrm{em}}(\mathrm{nm})$ & $\Delta \mathrm{S}^{[\mathrm{a}]}\left(\mathrm{cm}^{-1}\right)$ & $\Phi_{\mathrm{F}}{ }^{[\mathrm{b}]}$ & $\tau^{[\mathrm{c}]}(\mathrm{ns})$ & $\mathrm{k}_{\mathrm{r}}^{[\mathrm{d}]}\left(10^{8} \mathrm{~s}^{-1}\right)$ & $\mathrm{k}_{\mathrm{nr}}^{[\mathrm{d}]}\left(10^{8} \mathrm{~s}^{-1}\right)$ \\
\hline toluene & 389 & 33200 & $470 / 571$ & 4400 & 0.08 & $1.0 / 2.1$ & 0.53 & 6.13 \\
\hline EtOAc & 382 & 24000 & $508 / 555$ & 6500 & 0.13 & $1.5 / 2.9$ & 0.57 & 3.78 \\
\hline $\mathrm{CH}_{2} \mathrm{Cl}_{2}$ & 383 & 29700 & $514 / 565$ & 6700 & 0.17 & $1.7 / 3.7$ & 0.63 & 3.07 \\
\hline $\mathrm{CH}_{2} \mathrm{Cl}_{2}+\mathrm{HCl}_{g}$ & 358 & 27500 & 552 & 9800 & 0.06 & 0.7 & 0.86 & 13.40 \\
\hline $\mathrm{EtOH}$ & 390 & 27800 & $516 / 582$ & 6300 & 0.06 & $0.3 / 2.6$ & 0.40 & 6.27 \\
\hline $\mathrm{CH}_{3} \mathrm{CN}$ & 382 & 35100 & 579 & 8900 & 0.10 & 2.1 & 0.48 & 4.29 \\
\hline DMSO & 386 & 27800 & 573 & 8500 & 0.12 & $1.3 / 4.4$ & 0.43 & 3.14 \\
\hline $\mathrm{PBS}^{[\mathrm{e}]}$ & 378 & 18500 & $506 / 571$ & 6700 & 0.04 & 0.8 & 0.50 & 12.00 \\
\hline $\mathrm{PS}^{[\mathrm{f}]}$ & $313 / 394^{[\mathrm{g}]}$ & & $477 / 568$ & 4400 & 0.12 & & & \\
\hline PMMA $^{[\mathrm{ff}}$ & $331 / 382^{[g]}$ & & $479 / 565$ & 5300 & 0.24 & & & \\
\hline
\end{tabular}

a Stokes shift.

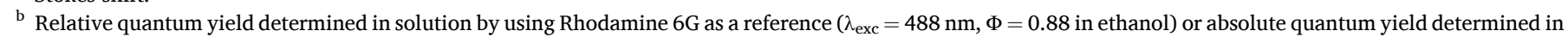
films using an integration sphere.

c Fluorescence lifetimes recorded upon excitation at $370 \mathrm{~nm}$.

${ }^{d} \mathrm{k}_{\mathrm{r}}\left(10^{8} \mathrm{~s}^{-1}\right)$ and $\mathrm{k}_{\mathrm{nr}}\left(10^{8} \mathrm{~s}^{-1}\right)$ were calculated using: $\mathrm{k}_{\mathrm{r}}=\Phi_{\mathrm{F}} / \sigma, \mathrm{k}_{\mathrm{nr}}=\left(1-\Phi_{\mathrm{F}}\right) / \sigma$ where $\sigma$ is the average lifetime.

e PBS buffer $\mathrm{pH} 7.4$ with $1 \%$ of DMSO.

${ }^{f}$ As doped as $1 \% w t$ in poly(methylmethacrylate) (PMMA) or polystyrene (PS) films.

$\mathrm{g}$ Excitation wavelength.

Table 2

Photophysical data for HBBO dye 2 recorded in aerated solutions of various solvents at $25{ }^{\circ} \mathrm{C}$ and in the solid-state.

\begin{tabular}{|c|c|c|c|c|c|c|c|c|}
\hline Solvent & $\lambda_{\mathrm{abs}}(\mathrm{nm})$ & $\varepsilon\left(\mathrm{M}^{-1} \cdot \mathrm{cm}^{-1}\right)$ & $\lambda_{\mathrm{em}}(\mathrm{nm})$ & $\Delta \mathrm{S}^{[\mathrm{a}]}\left(\mathrm{cm}^{-1}\right)$ & $\Phi_{\mathrm{F}}{ }^{[\mathrm{b}]}$ & $\tau^{[\mathrm{c}]}$ (ns) & $\mathrm{k}_{\mathrm{r}}^{[\mathrm{d}]}\left(10^{8} \mathrm{~s}^{-1}\right)$ & $\mathrm{k}_{\mathrm{nr}}^{[\mathrm{d}]}\left(10^{8} \mathrm{~s}^{-1}\right)$ \\
\hline toluene & 392 & 21000 & $482 / 584$ & 4800 & 0.11 & $1.1 / 2.4$ & 0.39 & 3.18 \\
\hline EtOAc & 392 & 24100 & 532 & 6800 & 0.17 & $1.8 / 3.2$ & 0.68 & 3.32 \\
\hline $\mathrm{CH}_{2} \mathrm{Cl}_{2}$ & 391 & 24100 & 547 & 7400 & 0.17 & $2.3 / 5.6$ & 0.43 & 2.08 \\
\hline $\mathrm{CH}_{2} \mathrm{Cl}_{2}+\mathrm{HCl}_{g}$ & 358 & 27600 & 564 & 9900 & 0.08 & $0.7 / 1.3$ & 0.80 & 9.20 \\
\hline EtOH & 391 & 16700 & $471 / 576$ & 8500 & 0.04 & $0.6 / 2.2$ & 0.29 & 6.86 \\
\hline $\mathrm{CH}_{3} \mathrm{CN}$ & 385 & 23300 & 599 & 9300 & 0.09 & $1.9 / 5.2$ & 0.25 & 2.53 \\
\hline DMSO & 390 & 20900 & 612 & 9200 & 0.06 & $1.7 / 5.0$ & 0.17 & 2.69 \\
\hline $\mathrm{PBS}^{[\mathrm{e}]}$ & 398 & 21100 & 546 & 6800 & 0.01 & 0.7 & 0.14 & 14.10 \\
\hline $\mathrm{PS}^{[\mathrm{ff}}$ & $331 / 398^{[g]}$ & & $481 / 575$ & 4300 & 0.07 & & & \\
\hline $\mathrm{PMMA}^{[\mathrm{ff}]}$ & $328 / 394^{[g]}$ & & $484 / 574$ & 4700 & 0.33 & & & \\
\hline
\end{tabular}

a Stokes shift.

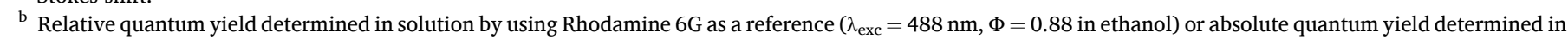
films using an integration sphere.

c Fluorescence lifetimes recorded upon excitation at $370 \mathrm{~nm}$.

${ }^{\mathrm{d}} \mathrm{k}_{\mathrm{r}}\left(10^{8} \mathrm{~s}^{-1}\right)$ and $\mathrm{k}_{\mathrm{nr}}\left(10^{8} \mathrm{~s}^{-1}\right)$ were calculated using: $\mathrm{k}_{\mathrm{r}}=\Phi_{\mathrm{F}} / \sigma, \mathrm{k}_{\mathrm{nr}}=\left(1-\Phi_{\mathrm{F}}\right) / \sigma$ where $\sigma$ is the average lifetime.

e PBS buffer pH 7.4 with $1 \%$ of DMSO.

${ }^{\mathrm{f}}$ As doped as 1\%wt in poly(methylmethacrylate) (PMMA) or polystyrene (PS) films.

g Excitation wavelength.

on the benzofuranol side. This does trigger a significant decrease of the acidity of the phenolic proton in the excited-state, leading eventually to the observation of a dual $\mathrm{E*} / \mathrm{K}^{*}$ emission. Indeed, the ESIPT process is under thermodynamic control and stabilization of the first excited-state, either by solvent interactions or electronic effects leads to a partial back proton transfer from the excited keto to the excited enol tautomer. The spectral separation between the $\mathrm{E}^{*}$ and the $\mathrm{K}^{*}$ bands is particularly pronounced in apolar toluene where a panchromatic emission is recorded, as evidenced by the observation of a white emission for $\mathbf{1}$ and $\mathbf{2}$ (see insets on Figs. 6 and 7).

Upon increase of the dipole moment of the solvent (from toluene to PBS buffer), the $E^{*}$ maximum emission wavelength undergoes a moderate but gradual bathochromic shift and does eventually coalesce with the $\mathrm{K}^{*}$ band. It is noteworthy that the $\mathrm{E}^{*} / \mathrm{K}^{*}$ intensity ratio is also highly dependent on both the physical characteristics of the solvent and the substitution on the benzoxazole side. These effects are particularly marked for HBBO 1 which is additionally substituted by a strong electron acceptor $\left(\mathrm{CF}_{3}\right)$ which does further contribute to the spectral separation between the two emission bands.

Protonation studies, performed by bubbling $\mathrm{HCl}_{g}$ in a solution of 1 in dichloromethane showed the disappearance of the dual emission system for the benefit of single emission band. This can explained by the likely decrease of the $\mathrm{pK}_{\mathrm{a}}{ }^{*}$ of the phenolic moiety induced by protonation of the 2-(2-methoxyethoxy)ethyl amino group. A slightly blueshifted $\mathrm{K}^{*}$ emission is also observed $\left(\lambda_{\mathrm{em}}=552 \mathrm{~nm} v s .565 \mathrm{~nm}\right.$ for the protonated and the neutral form of $\mathbf{1}$ respectively). It is difficult to interpret the protonation effect in HBBO 2 as both bands are heavily coalesced in the neutral state. The likely disappearance of the $\mathrm{E}^{*}$ band upon protonation results in the observation of the sole $\mathrm{K}^{*}$ emission at $564 \mathrm{~nm}$.

In solution, HBBO dyes $\mathbf{1}$ and $\mathbf{2}$ display quantum yields in expected ranges, as compared to similar dyes $(\phi=1-17 \%)[10,11]$. These mild values are the result of significant conformational changes in the excited-state. It is worth noting that these dyes showed a sizeable emission in highly protic pure PBS buffer solution at $\mathrm{pH} 7.4$, highlighting their potential use in biological imaging. These fluorophores showed in most cases a biexponential decay of the excited-state, evidencing the presence of the two excited tautomers. The average lifetime was typically in the nanosecond range, as expected for fluorescent organic dyes.

Investigation of the photophysical properties of HBBO dyes $\mathbf{1}$ and $\mathbf{2}$ was also carried out in the solid-state as doped in polymeric matrix (as $1 \% \mathrm{wt}$ in poly(methylmethacrylate) (PMMA) or polystyrene (PS) films). The emission spectra are presented in Fig. 8.

The emission spectra of $\mathbf{1}$ and $\mathbf{2}$ recorded as doped in polymers follow the same trend as in the solution-state. An intense dual $\mathrm{E}^{*} /$ $\mathrm{K} *$ emission is observed with maximum emission wavelengths peaking at $479 / 565 \mathrm{~nm}, 477 / 568 \mathrm{~nm}$ and $484 / 574 \mathrm{~nm}, 481 / 575 \mathrm{~nm}$ for $\mathbf{1}$ and 2, in PMMA and PS respectively. A distinct spectral separation is observed 


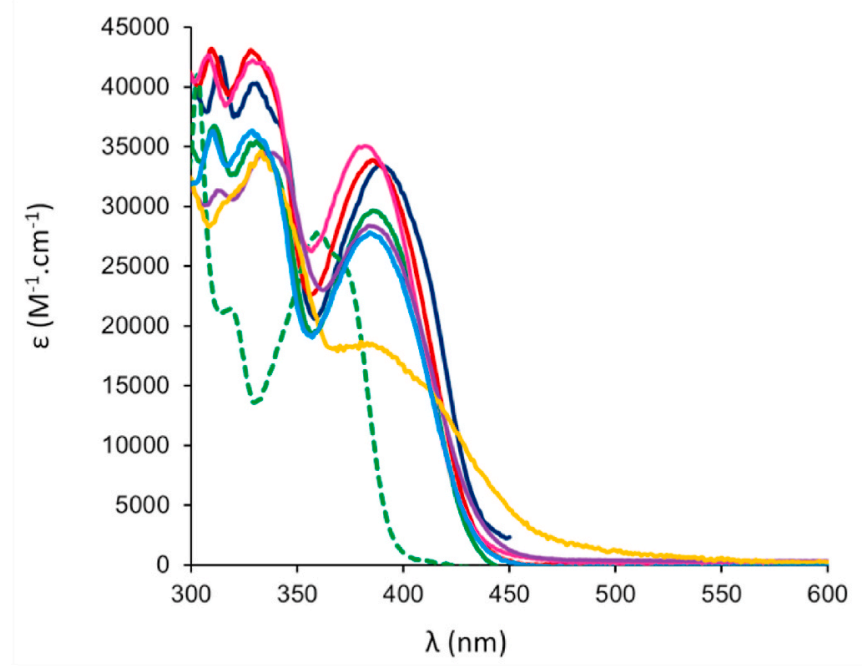

Fig. 4. UV-Vis spectra of HBBO 1 in toluene (navy blue), ethyl acetate (red), dichloromethane in neutral (plain green) and protonated (dotted green) states, ethanol (light blue), acetonitrile (pink), dimethylsulfoxide (purple) and PBS buffer (orange). (For interpretation of the references to colour in this figure legend, the reader is referred to the Web version of this article.)

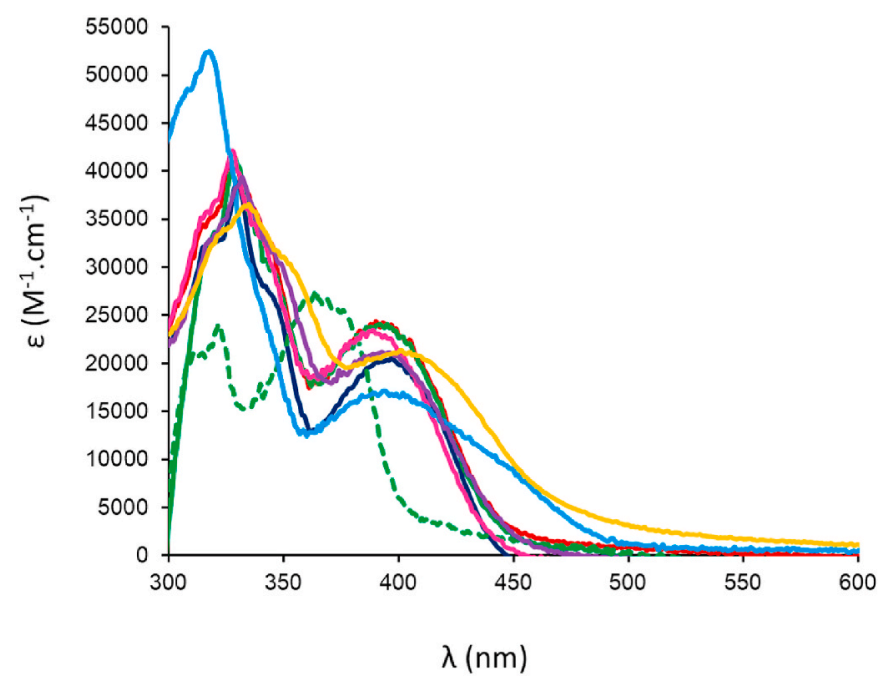

Fig. 5. UV-Vis spectra of HBBO 2 in toluene (navy blue), ethyl acetate (red), dichloromethane in neutral (plain green) and protonated (dotted green) states, ethanol (light blue), acetonitrile (pink), dimethylsulfoxide (purple) and PBS buffer (orange). (For interpretation of the references to colour in this figure legend, the reader is referred to the Web version of this article.)

between the two emission bands. The nature of the polymeric matrix does not seem to have a pronounced influence on the $\mathrm{E}^{*} / \mathrm{K} *$ intensity ratio. The quantum yields calculated from a spectrometer fitted with an integration sphere range between 7 and 33\%, which are slightly higher values than those recorded in solution, a feature typically observed for ESIPT emitters owing to the restriction of intramolecular rotations in a confined matrix.

\section{Biomolecules interactions}

The interactions between small molecules and biomacromolecules have been deeply scrutinized in order to shed some light on the mechanism of action of drugs and for the ultimate development of novel therapeutic agents as well as efficient diagnostic protocols [22]. DNA is often used as a model bio-target for these studies because of its defined

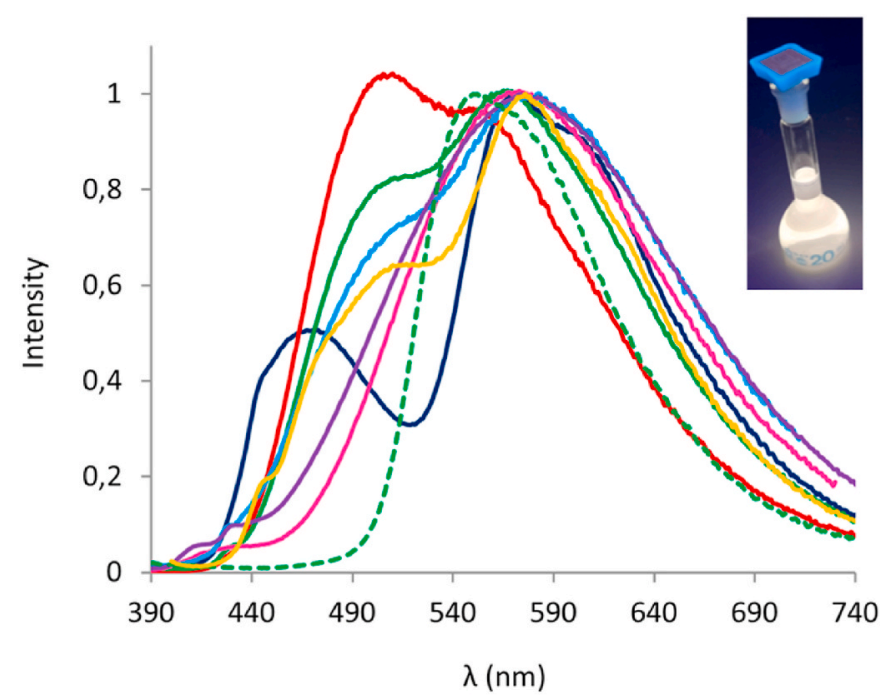

Fig. 6. Emission spectra of HBBO 1 toluene (navy blue), ethyl acetate (red), dichloromethane in neutral (plain green) and protonated (dotted green) states, ethanol (light blue), acetonitrile (pink), dimethylsulfoxide (purple) and PBS buffer (orange) $\left(\lambda_{\text {exc }}=390 \mathrm{~nm}\right)$ (inset: photograph of HBBO 1 in solution in toluene $(10 \mu \mathrm{M})$ under irradiation $\left(\lambda_{\text {exc }}=365 \mathrm{~nm}\right)$.). (For interpretation of the references to colour in this figure legend, the reader is referred to the Web version of this article.)

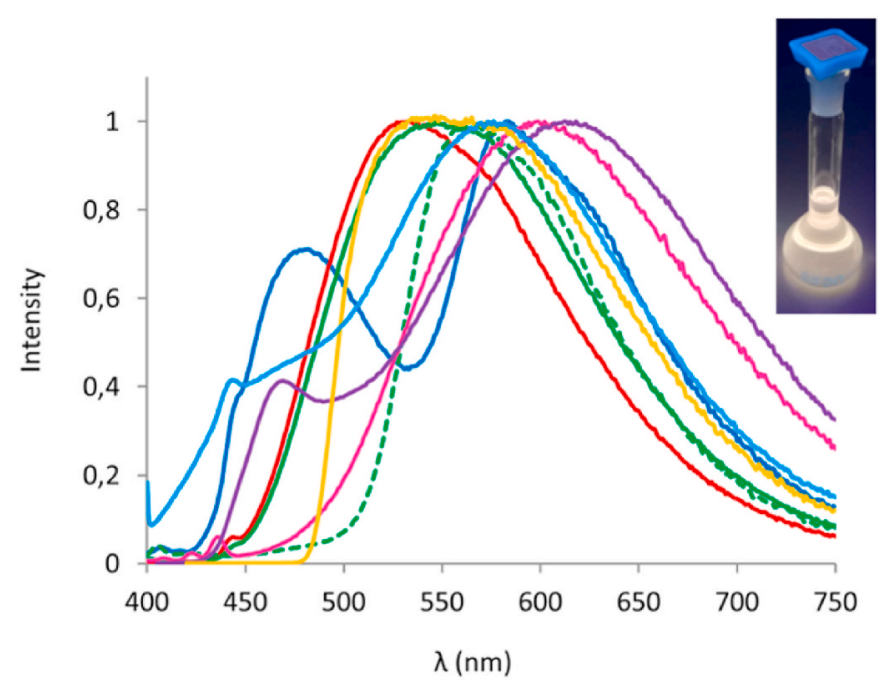

Fig. 7. Emission spectra of HBBO 2 toluene (navy blue), ethyl acetate (red), dichloromethane in neutral (plain green) and protonated (dotted green) states, ethanol (light blue), acetonitrile (pink), dimethylsulfoxide (purple) and PBS buffer (orange) $\left(\lambda_{\text {exc }}=390 \mathrm{~nm}\right.$ ) (inset: photograph of HBBO 2 in solution in toluene $(10 \mu \mathrm{M})$ under irradiation $\left(\lambda_{\text {exc }}=365 \mathrm{~nm}\right)$.). (For interpretation of the references to colour in this figure legend, the reader is referred to the Web version of this article.)

double helical structure and fundamental role as genetic material which does control many essential cellular activities including protein synthesis [23]. Non-toxic, biocompatible organic fluorophores, whose optical properties can be tuned depending on their immediate micro-environment, are valuable tools to probe interactions with DNA. Small aromatic molecules can bind to DNA through three main modes of interactions: $\pi-\pi$ stacking between adjacent base pairs of DNA (intercalation), major or minor groove binding involving van der Waals interactions or electrostatic binding between the negatively charged phosphate groups of DNA and charged species [24]. In the literature, the binding of many fluorophores to DNA is described [25] including that of 


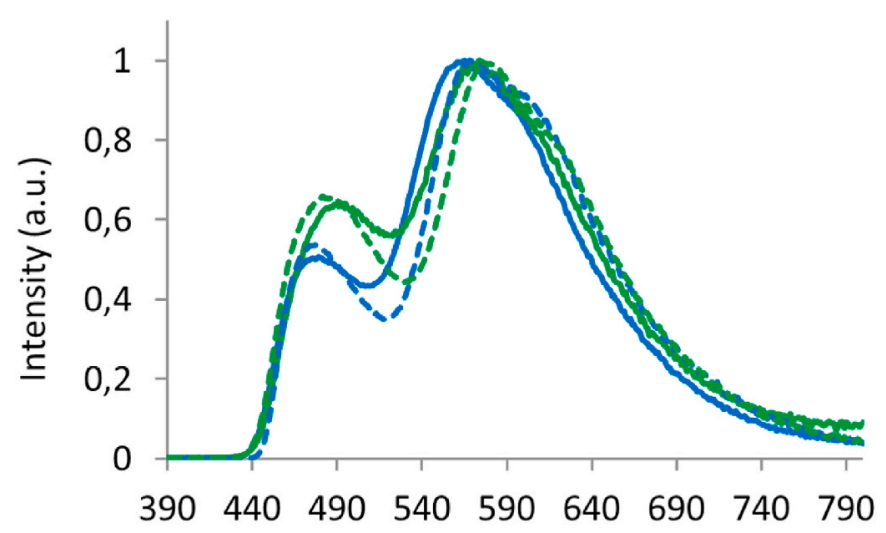

$$
\lambda(\mathrm{nm})
$$

Fig. 8. Emission spectra of HBBO dyes $\mathbf{1}$ (blue) and $\mathbf{2}$ (green) recorded in the solid-state as $1 \% w t$ doped in (a) PMMA films (plain line) and (b) PS films (dotted line) $\left(\lambda_{\text {exc }}=380 \mathrm{~nm}\right.$ ). (For interpretation of the references to colour in this figure legend, the reader is referred to the Web version of this article.)

ESIPT emitters like 3-hydroxyflavone [26]. Owing to their environment-dependent fluorescence profile, HBBO dyes appear to be particularly suitable to probe interactions with biomacromolecules like DNA. Moreover, in the case of $\mathbf{1}$ and 2, the 2-(2-methoxyethoxy)ethyl amino group present on the core of dyes strongly enhances their amphiphilicity and solubility in aqueous medium, and provides a good anchoring group for DNA binding through H-bonding as suggested by a recent publication [16].

HBBO dye 1 was chosen as a model compound to assess the possible interactions with DNA. The DNA binding studies were carried out by monitoring changes in the absorption and emission properties of dye $\mathbf{1}$ upon addition of increasing amounts of $c t$-DNA in a 1:1 mixture of $\mathrm{CH}_{3} \mathrm{CN} /$ Tris $\mathrm{HCl}$ buffer (pH 7.4) (Figs. 9 and 10).

In the absence of $c t$-DNA, HBBO 1 displays a relatively wide main absorption band centered on $380 \mathrm{~nm}$ attributed to the $\mathrm{S}_{0}-\mathrm{S}_{1}$ transition, along with other bands with maximum absorption wavelengths at 332 , 308 and $296 \mathrm{~nm}$. Addition of aliquots of $c t$-DNA $(0-100 \mu \mathrm{M})$ to dye 1 in

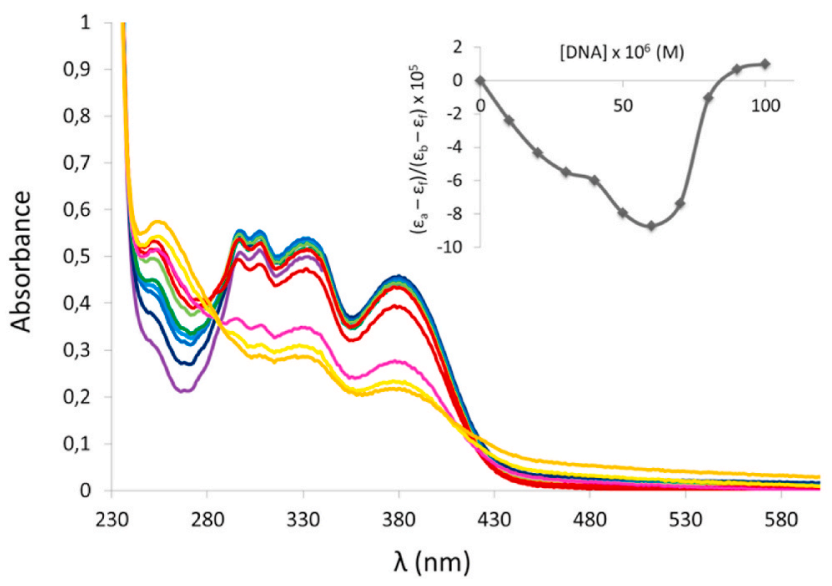

Fig. 9. Absorption spectra of HBBO $1(12 \mu \mathrm{M})$ in Tris $\mathrm{HCl}$ buffer $(\mathrm{pH} 7.4) /$ $\mathrm{CH}_{3} \mathrm{CN} 1: 1$ with increasing concentration of $c t$-DNA. Inset: Plot of $\left(\varepsilon_{\mathrm{a}}-\varepsilon_{\mathrm{f}}\right) /\left(\varepsilon_{\mathrm{b}}-\right.$ $\left.\varepsilon_{\mathrm{f}}\right) v s$ [DNA] at $332 \mathrm{~nm}$ with $\varepsilon_{\mathrm{a}}$, the absorption coefficient upon the addition of a given $c t$-DNA concentration, $\varepsilon_{\mathrm{f}}$, the absorption coefficient of the free compound and $\varepsilon_{\mathrm{b}}$, the absorption coefficient of the compound bound to ct-DNA. All spectra were corrected with dilution. Spectra of 1 with 0,60 and $100 \mu \mathrm{M}$ of $c t$-DNA are purple, red and orange curves respectively. (For interpretation of the references to colour in this figure legend, the reader is referred to the Web version of this article.)

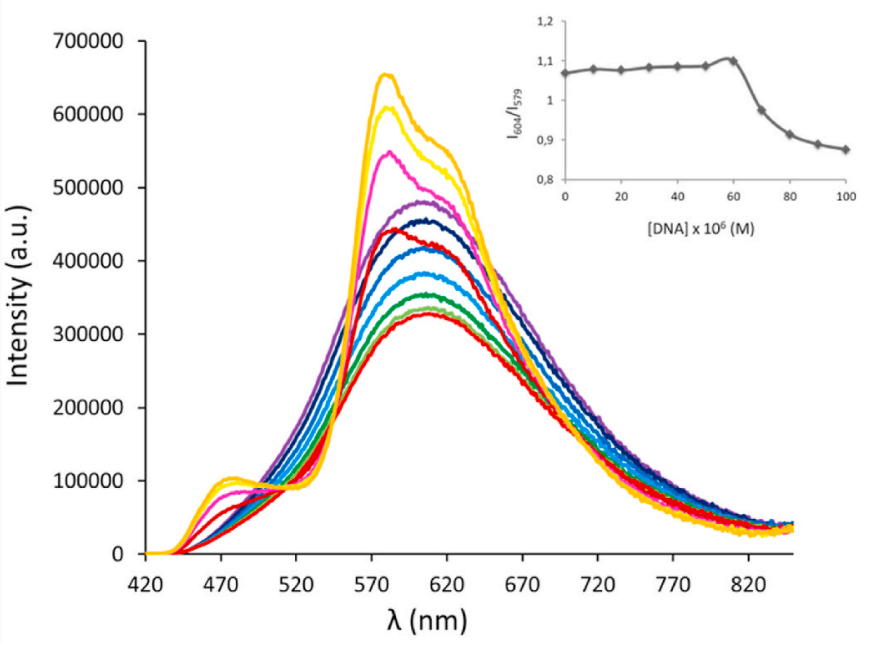

Fig. 10. Emission spectra of HBBO $1(12 \mu \mathrm{M})$ in Tris $\mathrm{HCl}$ buffer (pH 7.4)/ $\mathrm{CH}_{3} \mathrm{CN}$ 1:1 with increasing concentration of $c t$-DNA $\left(\lambda_{\text {exc }}=390 \mathrm{~nm}\right): 0 \mu \mathrm{M}$ (purple), $10 \mu \mathrm{M}$ (navy blue), $20 \mu \mathrm{M}$ (dark blue), $30 \mu \mathrm{M}$ (light blue), $40 \mu \mathrm{M}$ (dark green), $50 \mu \mathrm{M}$ (light green), $60 \mu \mathrm{M}$ (red), $70 \mu \mathrm{M}$ (burgundy), $80 \mu \mathrm{M}$ (pink), 90 $\mu \mathrm{M}$ (yellow), $100 \mu \mathrm{M}$ (orange). Inset: Plot $\mathrm{I}_{604 \mathrm{~nm}} / \mathrm{I}_{579} \mathrm{~nm}$ vs. [DNA]. (For interpretation of the references to colour in this figure legend, the reader is referred to the Web version of this article.)

solution led to significant changes in the absorption profile. First, upon addition of $10-60 \mu \mathrm{M}$, a gradual but moderate increase of the absorption coefficient is observed. However, the increase of the number of aliquots $(60-100 \mu \mathrm{M})$ triggered a marked decrease of the $\varepsilon$ value, reaching a plateau at $90 \mu \mathrm{M}$. This sizeable change at higher concentration of DNA could be indicative of a second mode of binding, occurring after an initial mode of interaction, a phenomenon already observed in the interactions of dyes with DNA [24,27]. It is to be noted that no change in the maximum absorption wavelength is observed.

In the absence of DNA, excitation in the main absorption band ( $\lambda_{\text {exc }}$ $=390 \mathrm{~nm}$ ) leads to the appearance of a broad emission band with a maximum emission wavelength at $604 \mathrm{~nm}$, attributed to the $\mathrm{K}^{*}$ decay (Fig. 10). Upon addition of the first aliquots of DNA (0-60 $\mu \mathrm{M})$, a slow decrease of the fluorescence intensity at $604 \mathrm{~nm}$ is observed. This fluorescence quenching could be possibly attributed to a photoinduced electron transfer (PET) process from the puric bases to the $\mathrm{K}^{*}$ state of HBBO 1, evidencing a first mode of interaction with DNA. Additional aliquots of DNA $(60-100 \mu \mathrm{M})$ trigger the rise of a main blue-shifted emission band $\left(\lambda_{\mathrm{em}}=579 \mathrm{~nm}\right)$, along with the appearance of a second band at higher energies $\left(\lambda_{\mathrm{em}}=475 \mathrm{~nm}\right)$. The observation of the typical $\mathrm{E}^{*} / \mathrm{K}^{*}$ dual emission of ESIPT emitters is consistent with a sudden change of environmental polarity. Intermolecular H-bonded interactions are known to stabilize the $\mathrm{E}^{*}$ tautomer which could mean that an intercalation mode of binding prevails at higher DNA concentrations. The full width at half maximum (FWHM) is also strongly reduced upon DNA binding (FWHM $=3540 \mathrm{~cm}^{-1}$ in the absence of DNA $v s$. FWHM $=$ $2740 \mathrm{~cm}^{-1}$ at $\left.100 \mu \mathrm{M}\right)$, highlighting a restriction of molecular motions, consistent with an intercalation mode. Finally, the excitation spectra (recorded at $\lambda_{\mathrm{em}}=610 \mathrm{~nm}$ ) follow the same trend as absorption spectra, excluding the presence of aggregates and ascertaining the presence of the molecular species in the excited-state in the presence of high concentration of DNA (Figure S5.1).

This unique optical signature appears to be a valuable tool to probe local environments in biomacromolecules. In order to expand the use of HBBO 1 as an intercalation probe for biomolecules outside nucleic acids, similar UV-Vis and fluorescence titrations were also performed with Bovine Serum Albumine (BSA), a model globular protein used in various biomedical applications [28]. The BSA binding studies were carried out by monitoring changes in the absorption and emission properties of 
HBBO 1 in a 1:1 mixture of DMSO/PBS buffer ( $\mathrm{pH} 7.4)$ upon addition of increasing amounts of BSA in PBS buffer (Figures S5.2 and S5.3). Addition of aliquots of BSA $(1-10 \mu \mathrm{M})$ leads to significant changes in the absorption and emission spectra profiles. Specifically, the absorption band of 1 , centered at $384 \mathrm{~nm}$ gradually decreases in the presence of BSA, concomitantly with the appearance of a broad absorption band characteristic of the BSA protein. Upon excitation at $390 \mathrm{~nm}$, in the absence of BSA, a single emission band centered at $575 \mathrm{~nm}$ is observed, attributed to the $\mathrm{K}^{*}$ decay. In a similar fashion as for DNA, addition of the first aliquots of BSA (1-4 $\mu \mathrm{M})$ leads to a gradual decrease of the intensity of the emission band which could be attributed to a detrimental PET process. Further aliquots $(5-10 \mu \mathrm{M})$ triggers the appearance of a second band at higher energies $\left(\lambda_{\mathrm{em}}=455 \mathrm{~nm}\right)$ along with a sizeable structuration of both emission bands. Moreover, the FWHM is also clearly reduced. These observations are consistent with the intercalation of the probes in rigid, apolar, hydrophobic pockets within the BSA where molecular movements are strongly restricted.

\section{Conclusions}

New HBBO-based ESIPT emitters incorporating a 2-(2-methoxyethoxy)ethyl amino group as electron donor have been synthesized and characterized. Owing to their highly amphiphilic character, these dyes exhibit an enhanced solubility in a wide range of solvent including PBS buffer at $\mathrm{pH}$ 7.4. Their photophysical properties were fully characterized in solution in a wide range of solvents and in the solid-state as $1 \% w t$ doped in polymers (PMMA and PS). A dual emission is observed in most solvents, corresponding to the decay from the excited tautomers $\mathrm{E}^{*}$ and $\mathrm{K}^{*}$. The interactions with $c t$-DNA and BSA with one of the dyes were also studied and a dual mode of binding was observed. First, detrimental interactions were noticed where the fluorescence intensity appeared to slowly quench followed by a possible intercalation in apolar environments, as evidenced by the appearance of the $\mathrm{E}^{*}$ band and a marked decrease of the FWHM. These results undoubtedly demonstrate that HBBO fluorophores can act as potential candidates for intercalation in biomolecules like DNA or BSA. Further studies in this direction are currently being investigated.

\section{Declaration of competing interest}

The authors declare no conflict of interests.

\section{Acknowledgments}

The authors are grateful to the Centre National de la Recherche Scientifique, the SATT Conectus (maturation project dualem) and the Agence Nationale de la Recherche (ANR project GeDeMi) for financial support.

\section{Appendix A. Supplementary data}

Supplementary data to this article can be found online at https://doi. org/10.1016/j.dyepig.2020.108895.

\section{References}

[1] (a) Zhao J, Ji S, Chen Y, Guo H, Yang P. Phys Chem Chem Phys 2012;14:8803-17. (b) Nishina N, Mutai T, Aihara J-I. J Phys Chem A 2017;121:151-61.(c) Klymchenko A. Acc Chem Res 2017;50:366-75.(d) Chen C-L, Chen Y-T, Demchenko AP, Chou P-T. Nat. Rev. Chem. 2018;2:131-43.(e) Padalkar VS, Seki S. Chem Soc Rev 2016;45:169-202.

[2] (a) Kwon JE, Park SY. Adv Mater 2011;23:3615-42.(b) Li B, Zhou L, Cheng H, Huang Q, Lan J, Zhou L, You J. Chem Sci 2018;9:1213-20.(c) Duarte LGTA, Germino JC, Berbigier JF, Aparecida Barboza C, Faleiros MM, de Alencar Simoni D, Tayar Galante M, Serra de Holanda M, Rodembusch FS, Atvars TDZ. Phys Chem, Chem Phys 2019;21:1172-82.(d) Duarte LGTA, Germino JC, Mendes RA,
Berbigier JF, Faleiros MM, Rodembusch FS, Atvars TDZ. Dyes Pigments 2019;171: 107671.

[3] (a) Sholokh M, Zamotaiev OM, Das R, Postupalenko VY, Richert L, Dujardin D, Zaporozhets OA, Pivovarenko VG, Klymchenko AS, Mély Y. J Phys Chem B 2015; 119:2585-95.(b) Wang L, Fujii M, Namba M, Yamaji M, Okamoto H. Tetrahedron Lett 2019;43:151189.(c) Wan J, Zhang W, Guo H, Liang JJ, Huang D, Xiao H. J Mater Chem C 2019;7:2240-9.

[4] (a) Pallavi P, Kumar V, Hussain MDW, Patra A. ACS Appl Mater Interfaces 2018; 10:44696-705.(b) Wang Q, Niu Y, Wang R, Wu H, Zhang Y. Chem Asian J 2018; 13:1735-43.

[5] (a) Singh P, Singh H, Sharma R, Bhargava G, Kumar S. J Mater Chem C 2016;4: 11180-9.(b) Barros HL, Mileski T, Dillenburg C, Stefani V. Forensic Chem 2017;5: 16-25.(c) Jagadesan P, Eder G, McGrier PL. J Mater Chem C 2017;5:5676-9.(d) Chen H, Feng Y, Deng G-J, Liu Z-X, He Y-M, Fan Q-H. Chem Eur J 2015;21: 11018-28.(e) Berbigier JF, Duarte LGTA, Zawacki MF, de Araujo BB, de Moura Santos C, Atvars TDZA, Gonçalves PFB, Petzhold CL, Rodembusch FS. ACS Appl. Polym. Mater. 2020;2(3):1406-16.(f) Duarte LGTA, Rodembusch FS, Atvars TDZ, Weiss RG. J Phys Chem A 2020;124(2):288-99.

[6] (a) Skonieczny K, Yoo J, Larsen JM, Espinoza EM, Barbasiewicz M, Vullev VI, Lee C-H, Gryko DT. Chem Eur J 2016;22:7485-96.(b) Suzuki N, Suda K, Yokogawa D, Kitoh-Nishioka H, Irle S, Ando A, Abegao LMG, Kamada K, Fukazawa A, Yamaguchi S. Chem Sci 2018;9:2666-73.(c) Zhang M, Cheng R, Lan J, Zhang H, Yan L, Pu X, Huang Z, Wu D, You J. Org Lett 2019;21(11): 4058-62.(d) Mishra VR, Ghanavatkar CW, Sekar N. Chemistry 2020;5:2103-13. (e) Massue J, Felouat A, Curtil M, Vérité PM, Jacquemin D, Ulrich G. Dyes Pigments 2019;160:915-22.

[7] (a) Massue J, Jacquemin D, Ulrich G. Chem Lett 2018;47:1083-9.(b) Azarias C, Budzák S, Laurent AD, Ulrich G, Jacquemin D. Chem Sci 2016;7:3763-74.(c) Yin H-Q, Yin F, Yin X-B. Chem Sci 2019;10:11103-9.

[8] (a) Jadhav AS, Carreira-Blanco C, Fernandez B, Gonzalez Fernandez S, Malkhede DD, Mosquera M, Ríos Rodríguez MC, Rodríguez-Prieto F. Dyes Pigments 2020;177:108285.(b) Munch M, Curtil M, Vérité PM, Jacquemin D, Massue J, Ulrich G. Eur J Org Chem 2019:1134-44.(c) Mena LD, Vera DMA, Baumgartner MT, Jimenez LB. Phys Chem, Chem Phys 2019;21:12331-40.

[9] (a) Park S, Kwon JE, Kim SH, Seo J, Chung K, Park S-Y, Jang D-J, Medina BM, Gierschner J, Park SY. J Am Chem Soc 2009;131:14043-9.(b) Tang K-C, Chang MJ, Lin T-Y, Pan H-A, Fang T-C, Chen K-Y, Hung W-Y, Hsu Y-H, Chou P-T. J Am Chem Soc 2011;133:17738-45.

[10] Benelhadj K, Muzuzu W, Massue J, Retailleau P, Charaf-Eddin A, Laurent AD, Jacquemin D, Ulrich G, Ziessel R. Chem Eur J 2014;20:12843-57.

[11] (a) Heyer E, Benelhadj K, Budzák S, Jacquemin D, Massue J, Ulrich G. Chem Eur J 2017;23:7324-36.(b) Heyer E, Massue J, Ulrich G. Dyes Pigments 2017;143: 18-24.

[12] (a) Fernández-Suárez M, Ting AY. Nat Rev Mol Cell Biol 2008:9:929-43.(b) Kaloyanova S, Zagranyarski Y, Ritz S, Hanulová M, Koynov K, Vonderheit A, Müllen K, Peneva K. J Am Chem Soc 2016;8:2881-4.

[13] (a) Gallavardin T, Maurin M, Marotte S, Simon T, Gabudean A-M, Bretonniere Y, Lindgren M, Lerouge F, Baldeck PL, Stephan O, Leverrier Y, Marvel J, Parola S, Maury O, Andraud C. Photochem Photobiol Sci 2011;10:1216-25.(b) Frath D, Didier D, Mély Y, Massue J, Ulrich G. ChemPhotoChem 2017;1:109-12.

[14] (a) Lavis LD, Raines RT. ACS Chem Biol 2014;9:855-66.(b) Lin H-A, Sato Y, Segawa Y, Nishihara T, Sugimoto N, Scott LT, Higashiyama T, Itami K. Angew Chem, Int Ed 2018;57:2874-8.

[15] Felouat A, Curtil M, Massue J, Ulrich G. New J Chem 2019;43:9162-9.

[16] Shi P, Jiang Q, Zhang Q, Tian Y. J Organomet Chem 2016;804:66-72.

[17] (a) Klymchenko AS, Mely Y. Prog. Mol. Biol. Transl. Sci. 2013;113:35-58.(b) Klymchenko AS, Stoeckel H, Takeda K, Mely Y. J Phys Chem B 2006;110: 13624-32.

[18] Schelkle KM, Griesbaum T, Ollech D, Becht S, Buckup T, Hamburger M, Wombacher R. Angew Chem, Int Ed 2015;54:2825-9.

[19] Jahnke E, Weiss J, Neuhaus S, Hoheisel TN, Frauenrath H. Chem Eur J 2009;15(2): $388-404$.

[20] It was not possible to observe the molecular peak on HR-MS for HBBO dye 2.

[21] (a) Rios Vazquez S, Rios Rodriguez MC, Mosquera M, Rodriguez-Prieto F. J Phys Chem A 2008;112(3):376-87.(b) Rios Vazquez S, Rios Rodriguez MC, Mosquera M, Rodriguez-Prieto F. J Phys Chem A 2007;111(10):1814-26.

[22] Prescher JA, Bertozzi CR. Nat Chem Biol 2005;1(1):1321.

[23] Rehman SU, Sarwar T, Husain MA, Ishqi HM, Tabish M. Arch Biochem Biophys 2015;576:49-60.

[24] (a) Chen H, Chen G, Du F, Fu Q, Zhao Y, Tang Z. RSC Adv 2013;3:16251-4.(b) Li X-L, Hu Y-J, Wang H, Yu B-Q, Yue H-L. Biomacromolecules 2012;13(3):873-80.

[25] (a) Mallick T, Karmakar A, Batuta S, Ahamed G, Das S, Alam MN, Mukherjee M, Das N, Mandal D, Ara Begum N. ACS Omega 2018;3:334-48.(b) Veale E, Gunnlaugsson T. J Org Chem 2010;75:5513-25.(c) Sepay N, Guha C, Maity S, Mallik AK. Eur J Org Chem 2017:6013-22.

[26] (a) Jana B, Senapati S, Ghosh D, Bose D, Chattopadhyay N. J Phys Chem B 2012; 116:639-45.(b) Tu B, Chen Z-F, Liu Z-J, Cheng L-Y, Hu Y-J. RSC Adv 2015;5: 33058-66.(c) Karmakar A, Mallick T, Alam MN, Das S, Batuta S, Chandra SK, Mandal D, Ara Begum N. J Mol Struct 2018;1165:276-87.

[27] Tuite E, Kelly JM. Biopolymers 1995;35:419-33.

[28] (a) Sulkowska A. J Mol Struct 2002;614:227-32.(b) Wang J, Zhang B. Curr Med Chem 2018;25:2938-53.(c) Jahanban-Esfahlan A, Ostadrahimi A, JahanbanEsfahlan R, Roufegarinejad L, Tabibiazar M, Amarowicz R. Int J Biol Macromol 2019;138:602-17. 